\title{
Chemical hazard exposure as a result of waste land filling: a review
}

\author{
M. E. El Megrahi, G. Karani \& K. Morris \\ Cardiff School of Health Sciences, University of Wales Institute Cardiff, \\ Wales, UK
}

\begin{abstract}
Waste is any substance that is discarded, emitted or deposited in the environment in such volume, constituencies or manner as to cause damage in the environment. Waste can include domestic waste, commercial waste, industrial, medical and radioactive material. All types of wastes are deposited in the environmental ecosystem frequently by the land filling process. Land filling is one of the methods used to reduce and manage the waste as well as being the most common method by which waste is disposed of in the UK. After dumping the waste in landfill sites, several chemical hazard materials such as volatile organic compounds, (VOCs), methane, heavy metals, dioxin, furan, hydrogen sulphide and natural occurrence radioactive material (NORM) are vented to environment as result of several biological and chemical processes occurring in the landfill site. This paper is a review of the current knowledge on the importance of monitoring of chemical hazards and its effects on environment and health.
\end{abstract}

Keywords: land filling, sources, monitoring, chemical hazard, exposure.

\section{Introduction}

The quantity of waste generated has considerably increased for several reasons, but major factor is lifestyle improvement and the increase in consumption of food and goods associated with it. However, another factor associated with increased waste production is the extension in industries throughout the world. While this expansion in industrial capacity offers more diversity in production, the increased waste production brings with it considerable associated problems. In addition, waste disposal is subject to legislation governing treatment before 
land filling. However, in many countries such legislation either does not exist or is not sufficiently implemented. There has emerged increasingly the necessity of environmental waste management systems. Landfill is a place used to dispose waste. These are normally in the form of cells which can be lined, then filled with waste materials which are progressively compressed and enclosed with further soil, and finally stored with a permanent cap.

Land filling is one of the most frequently used options for safe disposal of domestic, commercial and industrial waste. Landfill is generally regarded as the simplest and most cost-effective method of disposing of waste, Barrett and Lawlor [1].

In most low-to medium-income developing nations, almost $100 \%$ of generated waste goes into landfill. Even in many developed countries, most solid waste is land filled In the UK landfill continues to be the most common method for waste disposal. In 2004 Wales generated an estimated 14.5 million tones of waste EPW [2]. Consequently, Wales in 2007 may face a critical crisis as result of waste land filling. DEFRA [3]. Furthermore although the proportion of waste to landfill may in future decrease, the total volumes of municipal solid waste being produced are still increasing at a rate in excess of $3 \%$ per year, Douglas [4].

Land filling is likely to remain a relevant source of ground water contamination for the foreseeable future, Allen [5] and as several unlined landfill sites in UK are situated on major aquifers, the potential impact on the water table needs to be investigated, Bloor et al. [6].

\section{Source of chemical hazard exposure from land filling}

Waste is a mixture of packaging materials, food cans, biodegradable waste and garden waste, commercial and industrial waste. Solid household waste contains between $40-90 \%$ moisture and contains levels of soluble organic compound which can play major role to the growth of unnecessary bacteria. These may lead to the generation of toxic substances through chemical and biological processes such as, hydrolysis, fermentation, cytogenesis, and methanogenesis, oxidation, Satheropouls [7].

\subsection{Volatile organic compounds (VOCs)}

VOCs are compounds that have a high vapour pressure greater than $0.0013 \mathrm{~atm}$ at standard temperature and low water solubility. VOCs can be classified as several types; Halogenated Volatile organic compounds, oxygenated VOCs, sulphanted VOCs, and aliphatic, aromatic VOCs, Hamideh [8].

\subsection{Dioxins and furans}

Dioxins are chlorinated dibenzo-paradioxine and are formed during the composition of material containing chlorine. Dioxins and furans are released into the atmosphere as by products of many combustion processes. These includes the incineration of municipal waste, the burning of fuels including coal, oil, and 
also some industrial processes such as bleaching pulp, paper and combustion of landfill gas, ASTDR [9]

\subsection{Heavy metals}

Heavy metals are defined as metals that have specific density of more than $5 \mathrm{~g} / \mathrm{m}^{3}$. Metals account for a approximately one-quarter of the earths mass. The majority of metals occur in nature as natural ores, which are compounds of the metal combined with typically oxygen and sulphur. Common heavy metals found in landfill are cadmium, mercury, arsenic and lead, Jarup [10].

\subsection{Acid gas}

Acid gases such as nitrogen oxide, sulphur dioxide, carbon monoxide can be released as result of decomposition of waste and gas flaring landfill site. Tennessee Division of Solid Waste Management Programme [11].

\subsection{Odour}

Odour is an oraganoleptic attribute Perceptible by the olfactory organ on sniffing certain volatile substances, CEN: [12]

Most landfill sites release nuisance odour especially when a lot of putrescible wastes are dumped in the site. In some cases landfill odours have been traced over $1 \mathrm{~km}$. There is suggestion that odour is result of hydrogen sulphide, dimethyl sulphide, and mercaptans found in the landfill site and may produce strong rotten-egg sell even in very low concentration, El-Fadel et al. [13].

\subsection{Methane}

Methane is the most common gas emitted from landfill as result of waste decomposition in the absences of oxygen. Landfills are the single largest sources of U.S. man-made methane emissions, ASTDR [14].

\subsection{Natural radioactivity}

Radioactivity is spontaneous nuclear transformation that results in the formation of new elements. These transformations are accomplished by emission of particles from the nucleus or by the capture of orbital electron.

Each of these reactions may or may not be accompanied by a gamma photon, WHO [15]. Around $90 \%$ of human radiation exposure comes from natural sources such as cosmic radiation, exposure to radon and terrestrial radiation. However some industrial process such as coal, peat, mineral, sands by- product may enhance radionuclide to such a degree that they may pose risk to human and environment if they are not controlled, Organo and Lee [16].

\section{Environmental problems caused by land filling emissions}

The deposition and burning of waste cause a profound strain on the environment with its potential to contaminate ground water resources, emit gases cause air 
and soil contamination, Poulsen et al. [17]. Air quality has become a major interest in area where several waste facilities are located. This interest is based on the increased odour and emission vented from landfill. On global scale, landfills are responsible for about $10 \%$ of human intrusion methane.

Landfill gas collection systems do not prevent significant emission of the harmful greenhouse gas, methane, from landfills. In fact, less than $50 \%$ and possibly only $10-20 \%$ of methane produced is likely to be captured as result of collection systems. In order to prevent an explosive mixture oxygen and methane gas is drawn from the landfill with vacuum pumps. The vertical collection pipes cannot be properly perforated at the top third of the pipe; moreover, the pipes cannot extend to the very bottom of the waste, United Nations Environment Programme [18].

The magnitude of annual global emission of methane from municipal solid waste landfills without landfill gas control system implies that these landfills are significant contributors to the atmospheric load of green house gases Fourie and Morris [19].

Study on ambient air monitoring by, $\mathrm{Zu}$ et al. [20] at Datianshan landfill, Guangzhou, South China in 1998 to investigate the seasonal and horizontal variations of trace volatile organic compounds (VOCs) identified thirty eight vocs in the winter, whereas 60 were detected in the summer.

Study by Tolvanen et al. [21] to investigate the abundance of volatile organic compounds within landfill site; found that the common VOCs were found are aldehydes, carboxylic acids, ketones. Landfill leachate contains wide range of toxic substances arising from the decomposition of waste, and causes contaminates of domestic groundwater sources and excess of nitrogen in watercourses. Substances found in leachate from household waste such as toluene and mercury, are toxic to living organisms that come into contact with leachate-contaminated water or soil (Slack et al. [22]).

Research on the impact of peat by- product land filling in Ireland has been undertaken. Although the study confirmed that there was low exposure due to natural occurrence radioactivity material in the peat used in producing electricity in Ireland, the study did not expand on the inhalation of peat ash dust on the landfill sites arising from the generation of windborne ash on the ash pond, Organo [23] Furthermore the study did not investigate the possibility of leaching of Ra- 226 from ash pond to underground water underneath the ash pond and the transport of dry ash by wind to different residential and agricultural area. Moreover internal and external radiation exposure to the public may occur when some of the ash may be used as building material.

\section{Health problems caused by land filling emissions}

Health is defined as a state of complete physical, mental and social well-being and not totally the absences of disease or infirmity, WHO [24].

Concern about possible adverse health effects for population living nearby land fill sites and have been highlighted, especially in relation to those sites where hazardous waste is dumped Vrijheid [25]. 
Several studies on occupational exposure or health problems in waste facilities carried out in the USA, Mandsdorf et al., [26] Great Britain,

The studies of Crooks et al., [27] and Rahkonen, [28] have indicated that workers in this industry have an excess risk of work- related health problems such as musculoskeletal problems, pulmonary diseases, organic dust toxic syndrome (ODTS) symptoms (cough, chest-tightness, dyspnoea, influenza-like symptoms such as chills, fever, muscle ache, joint pain, fatigue and headache), gastrointestinal problems and irritation of the eye, skin and mucous membranes.

Hertzman et al., [29] stated that people who lived or worked near an industrial dump revealed significantly elevated the following symptoms bronchitis; difficulty berating; cough; skin rash; hearth problems; muscle weaknesses. Paigen and Goldman [30] stated children living near the chemical waste dump in love canal Niagara Falls showed significantly reduced height compared with a control group of children living further from the dump site.

Berry and Bove [31] studied birth weight at the Lipari Landfill in New Jersey, a site for municipal and industrial waste. Leachate from the site migrated into nearby streams and a lake adjacent to a residential area. Inhalation of volatile chemicals emitted from the landfill and contaminated waters was thought to be the most important exposure pathway. The site closed in 1971 after complaints of residents, but the heaviest pollution was estimated to have occurred during the late 1960s to the mid-1970s. The study found a convincing increase in proportion of low birth weight babies $(<2500 \mathrm{~g})$ and a lower average birth weight in the population living closest (within a radius of $1 \mathrm{~km}$ ) to the landfill in the time period when potential for exposure was thought to be greatest (1971-1975) compared to these factors in a control population.

Study by Kharrazi et al. [32] at BBK landfill California sites detected waste of a significant association disposal waste and the weight foetal, with a negative correlation between mortality rate and waste disposed.

Dolk et al. [33] noticed the risk of congenital anomaly in babies whose mothers lived close to landfill sites was in both the study and control areas. The authors felt that direct measure of exposures and birth defects would better establish a causal relationship.

Study on the health impact of waste on workers and domestic waste collectors showed signs of increased prevalence of respiratory symptoms and also increased concentrations of variables indicative of upper respiratory inflammation in nasal lavage compared with controls Wouters [34].

Although several researchers have addressed the risk of waste facilities, for instance congenital anomalies and malignancies in relation to living in closeproximity to landfill sites, the health impacts of new waste management technologies and the increasing use of recycling and composting will require further assessment and monitoring, Rushton [35].

Hamer [36] stated the effects of the waste management practices on public health and environment safety remain unanswered. 


\section{Conclusion}

In order to develop environmentally sound and sustainable waste management, it is necessary to establish research that focuses on modern analytical technique and use the latest sensory technology for the measurement and evolution of chemical hazard exposure.

Studies on natural occurrence radioactive material specific activity from waste land filling process limited and the potential sources of exposure is not characterised. In this context, natural radioactivity comprises vital subject, which need to be considered in updated landfill regulation and standards. This will help and enhance the limitation of radiation exposure risks emitted from NORM.

\section{Future research}

For the future planning and regulation of land filling, it is important to understand which types of sites are most likely poses risks. Research in to the environmental and health effects of land filling is relatively rare, and further research may improve our current understanding. This only through multidisciplinary approach drawing from the fields of environmental Sciences, toxicology and epidemiology.

Biological monitoring plays important role in industrial hygiene practice to evaluate the dose-response relationship between internal exposure and adverse health effects of exposure of chemical, there fore research would be worth doing it using biological marker as technique as tool to see the effect of waste on public and environmental species. More research into effects of chemical mixtures and possible interaction between single chemicals is needed to improve understanding of effects of multiple chemical exposures.

\section{References}

[1] Barrett, A., Lawlor, J. The economics of waste management in Ireland. Economic and Social Research Institute, Dublin, pp 129, 1995.

[2] EPW. Environment Protection Agency Wales, 2005

[3] Department for Environment food and Rural Affairs, Review of Environmental and Health Effects of Waste Management, London, UK, 2004.

[4] Douglas, T, Patterns of land, Water and air pollution by waste. In: Newson, M. (ed.) Managing the human impact on Natural Environment John Wiley \&Sons, 150-171,1992.

[5] Allen, a contaminated landfills: The myth of sustainability. J. Eng. Geol, 60, pp3-19, 2001.

[6] Bloor M.C, et al., Acute and sub lethal toxicity tests to monitor the impact of leachate on an aquatic environment, Environmental International, 31, pp.269-273, 2005. 
[7] Satheropouls M a study of volatile organic compounds evolved in urban waste disposal bins, Journal of AtmosphericEnvironment, 39,pp.46394645,2005.

[8] Hamideh Soltani Ahmadi, A Review of the literature Regarding NonMethane and Volatile Organic Compounds In Municipal Solid Waste Landfill Gas., SWANA/Hickman Intern, Department of Civil and Environmental Engineering, University of Delaware, Near, Delaware 19716, 2000.

[9] ASTDR Agency For Toxic Substances and Disease Registry, Landfill Gas Primer, An overview for Environmental Health Professionals, USA, 2001.

[10] Jarup Lars, Hazards of heavy metal contamination, British Medical Bulletin, 68 pp.167-182, 2003.

[11] Tennessee Division of Solid Waste Management Programme. Landfill Gas Monitoring and Mitigation. The technical Section/Solid Waste Management Programme, 1999.

[12] CEN: Air quality- Determination of Odour concentration by dynamic olfactmetry. CEN, European committee for standardization, Draft prEn13725, Brussels, 1999.

[13] El-Fadel, et al, $M$, Environmental impacts of solid waste land filling. Journal of Environmental Management, 50(1), 1997.

[14] ASTDR, op. cit.

[15] WHO, World Health Organization, Depleted Uranium Sources, exposure and health effect, Department of protection of the human environment, World Health Organization, Geneva, 2001.

[16] Organo C, E M, Lee Investigation of occupational radiation exposures to NORM at an Irish peat-fired power station and potential use of peat fly ash by construction industry, Journal of Radiological protection, 25, pp.461-474, 2005.

[17] Poulsen M. Otto, et al, Sorting and recycling of domestic waste. Review of occupational health problems and their possible causes, the sciences of the total Environment 168, pp.33-56, 1995.

[18] Agency, United Nation Environment Programme, Global Warming: National Emission. P table es, 2000.

[19] Fourie AB, Morris JW Measured gas emissions from four landfills in south Africa and some implications for landfill design and methane recovery in semi-arid climates, Waste Manag Res ;22(6) pp. 440-53, 2004.

[20] $\mathrm{Zu} \mathrm{C}$, et al, Characterization of ambient volatile organic compounds at a landfill site in Guangzhou, South China, Chemosphere. 51(9) pp. 1015-22, 2003.

[21] Tolvanen O, Nykanen J, Nivukoski U, et al, Occupational hygiene in a Finnish drum composting plant, Waste Manag;25(4) pp.427-33, 2005.

[22] Slack R J, et al, Household hazardous waste in municipal landfill: contaminates in leachate. Sci Total Environ 20; 337(1-3) pp.119-37, 2005.

[23] Organo C, op. cit.

[24] World Health Organization, (WHO) Definition of Health, 2005. 
[25] Vrijheid Martine, Health effects of residence Near hazardous waste Landfill sites: A Review of Epidemiologic Literature, Environmental health Perspective Supplements Volume 108, Number S1, March, 2000.

[26] Mandsdorf et al., Industrial Hygiene characterization and Aerobiology of Resource Recovery Systems. NIOSH, Morgantown, 1982.

[27] Crooks et al Airborne Microorganisms Associated with Domestic Waste Disposal. Crop Protection Division, AFRCA Institute of Arable Crops Research, Rothamasted Experimental Station, Harpenden, Herts, AL5 2JQ, pp.1-119. 1987.

[28] Rahkonen, P Airborne contaminates at waste treatment plants. Waste Management. Research, 10 pp. 411-421, 1992.

[29] Hertzman, et al, Upper Ottawa Street landfill site Health study" Environmental Health Perspectives. (75), pp581-97, 1987.

[30] Paigen B, Goldman LRR. Growth of Children living near the hazardous waste site, Love Canal. Hum Boil 59pp.489-508, 1987.

[31] Berry M \& Bove; Birth weight reduction associated with residence near a hazardous waste landfills, Environ Health Perspective. 105(8), pp856861. 1997.

[32] Kharrazi, Von Behren, J., Smith, M., A community based study of adverse pregnancy outcomes near a large hazardous waste landfill in California, Toxicol.Ind Health, 13 pp.229-310, 1997.

[33] Dolk H, et al, Risk of congenital anomalies near hazardous waste landfill sites in Europe: The EUROHAZCON Study. Lancet. 352, pp, 423-27, 1998.

[34] Wouters, I .M. Upper Air inflammation and respiratory symptoms in domestic waste collectors, Journal Occupational and Environmental Medicine. 59, pp 106-112. , 2002.

[35] Rushton L. Health hazards and waste management. Br Med Bull. 68, pp183-97. 2003.

[36] Hamer Geoffrey Solid waste treatment and disposal: effects on public and environment, Biotechnology advance, 22, 1-2, 77-79, 2003. 